\title{
Piekło kobiet - współczesny obraz prawa do aborcji w przestrzeni medialnej. Casus niewolenia kobiet czy ich emancypacji?
}

Powstało wiele pozycji na temat aborcji, tak więc artykuł ten z pewnością nie omówi w sposób wyczerpujący wszystkich wątków i kontekstów dotyczących tej kwestii. W Polsce - oprócz publikacji naukowych - powstają liczne dokumenty, artykuły, broszury informacyjne, wyniki badań różnych organizacji (Federacja na Rzecz Kobiet i Planowania Rodziny, Human Life International i inne), coroczne sprawozdania Rady Ministrów z działalności ustawy czy raporty Komisarza Praw Człowieka.

Pojawiły się także opracowania podejmujące tematykę języka używanego w dyskursie dotyczącym aborcji. Wśród nich należy wymienić prace Anny Matuchniak-Krasuskiej (1995), Agnieszki Graff (2001), Katarzyny Gawlicz (2005) i Eweliny Wejbert-Wąsiewicz (2012). Każda z badaczek zwróciła uwagę na zmiany zachodzące w języku i stopniowe „znikanie” kobiet z przestrzeni publicznej.

Anna Matuchniak-Krasuska, analizując język ekspertów pro-life, ujawniła szereg manipulacji semantycznych, takich jak: likwidacja terminów neutralnych, wprowadzenie odpowiednich synonimów, wykluczenie pewnych sformułowań, przedefiniowanie innych. Terminy „embrion” czy „płód” zastąpiono zwrotami "dziecko nienarodzone" czy "dziecko w łonie matki”, a w miejsce terminu „kobieta” pojawiło się słowo „matka”. Z kolei aborcja to „zabójstwo”, „morderstwo” lub „wewnątrzmaciczne okaleczanie dziecka”, a lekarz dokonujący zabiegu to „aborter”, „morderca niewinnych” (Matuchniak-Krasuska 1995).

Agnieszka Graff w felietonie Znikajacca kobieta - czyli polskie rozmowy o prawie do aborcji napisała, że w debacie publicznej na temat prawa kobiet do zabiegu przerwania ciąży liczy się nie tylko moc argumentów, ale także siła głosu, ponieważ chodzi o to, czyj pogląd i czyj język stanie się obowiązujący dla wszystkich. Jej zdaniem w Polsce uprawomocnił się sposób myślenia, mówienia i wartościowania w kwestii aborcji, który ma rację bytu wyłącznie na gruncie religijnym (Graff 2001: 112). Feministka przyczyn „znikania” kobiet w owej debacie upatrywała w przegranej środowisk opowiadających się za wolnym wyborem w wojnie o język.

Zdaniem Katarzyny Gawlicz dyskusje o aborcji toczone w Polsce już wyszły poza kontekst wyznaczany przez myślenie o sytuacji kobiet i ich prawach, a sytuowane są zwykle w obrębie dyskursu moralności określającego, czym jest aborcja 
(Gawlicz 2005: 99). Autorka w artykule Płeć i naród. Dyskurs dotyczacy aborcji w "Naszym Dzienniku" a konstruowanie tożsamości narodowej stwierdziła także, że w sposobie mówienia o aborcji dominuje dyskurs moralności. W dyskursie narodowościowym jednak (obejmuje on koncepcję moralności, w myśl której aborcja jest morderstwem, ale niesprowadzalny tylko do niej) aborcja jest wykorzystywana jako instrument do budowania i podtrzymywania określonej wizji polskiej tożsamości narodowej.

Z kolei Ewelina Wejbert-Wąsiewicz w książce Aborcja w dyskursie publicznym. Monografia zjawiska zwróciła uwagę, że kiedy kwestia dopuszczalności aborcji przeniosła się z forum parlamentu do szeroko pojętego dyskursu publicznego, nastąpił podział społeczeństwa, w którym zwolenników zachowania prawa do aborcji nazwano zwolennikami „cywilizacji śmierci”, a popierających projekt ustawy delegalizującej aborcję „zwolennikami ciemnoty, zacofania i średniowiecza, mordercami kobiet". Kolejnym krokiem było wyróżnienie zwolenników pro-life (opowiadających się za życiem) i pro-choice (występujących przeciw życiu). Autorka z perspektywy czasu stwierdziła, że „bitwę o język” wygrali zwolennicy zakazu aborcji (Wejbert-Wąsiewicz 2012: 84).

\section{Zakaz aborcji a systemy totalitarne}

W latach trzydziestych XX wieku w kwestii praw reprodukcyjnych kobiet Adolf Hitler, Benito Mussolini, Józef Stalin i Kościół katolicki wyrażali to samo zdanie zadaniem kobiety jest rodzenie dzieci. Mussolini planował celowe przeludnienie w celach kolonialnych, z kolei w Rosji rewolucja przyniosła najpierw względny liberalizm w sprawach płci, by kilkanaście lat później zastąpić go polityką mnożenia ludzi sowieckich na wzór włoski - całkowity zakaz aborcji, utrudnianie rozwodów i premie dla matek-przodowniczek. W III Rzeszy równolegle wprowadzono natomiast drastyczne kary za spędzenie płodu, a podręczniki antykoncepcji palono na stosach (Zaremba-Bielawski 2011: 348). Władze III Rzeszy konsekwentnie likwidowały poradnie planowania rodziny, a Führer nagradzał wielodzietne Niemki Krzyżem Matki ${ }^{1}$. Propaganda nazistowska traktowała prawa kobiet - a zwłaszcza prawo do aborcji - jako przejaw komunistyczno-żydowskiego spisku przeciwko Rzeszy (Graff 2001: 133). Restrykcyjne ustawodawstwo dotyczyło tylko Niemek. Polki mogły dokonywać aborcji bez żadnych przeszkód, ponieważ zostały uznane przez nazistów za „element małowartościowy”, który należało eksterminować. Adolf Hitler napisał w Mein Kampf: „Prawo do wolności osobistej zanika w obliczu obowiązku zachowania rasy; musimy pozbyć się myśli, że stosunek do własnego ciała jest sprawą jednostki" (Hitler cyt. za: Steinem 1983: 309)². W 1934 roku, podczas

1 Ehrenkreuz der Deutschen Mutter (Mutterkreuz) - ustanowiony przez Hitlera order w formie krzyża, przyznawany na mocy rozporządzenia z 16 grudnia 1938 roku wielodzietnym matkom w trzech klasach: brązowej (za czworo-pięcioro dzieci), srebrnej (za sześcioro-siedmioro) i złotej (za ośmioro i więcej dzieci). Odznaczenie nadawano w ramach „wojny urodzeń" i otrzymać go mogły tylko kobiety spełniające kryteria rasowe. Wykluczano matki „aspołeczne” oraz „rasowo" lub „umysłowo małowartościowe".

${ }^{2}$ Tłumaczenia - A.B., jeśli nie zaznaczono inaczej. 
przemówienia do Narodowosocjalistycznej Organizacji Kobiet mówił: „Każde dziecko, które kobieta wyda na świat, to bitwa, bitwa stoczona dla dobra narodu" (Hitler cyt. za: Steinem 1983: 319).

Podobnie wyglądała sytuacja kobiet w Rumunii za rządów Eleny i Nicolae Ceauşescu. Dnia 1 października 1966 roku ogłoszono dekret, który określał aborcję jako poważny występek przeciw zdrowiu, mający negatywny wpływ na wzrost populacji. Jedynymi dopuszczalnymi wyjątkami były kazirodztwo i gwałt. Z początkiem lat osiemdziesiątych XX wieku wprowadzono dla kobiet obowiązek częstych wizyt sanitarnych i ginekologicznych, podczas których lekarz miał sprawdzić, czy nie doszło do nielegalnego zabiegu przerwania ciąży. Każda kobieta co miesiąc w swoim miejscu pracy była poddawana obowiązkowo takiemu badaniu.

Elena Ceauşescu mówiła do swoich studentek:

Nie zwracajcie uwagi na waszych zacofanych rodziców. Nie czekajcie z uprawianiem miłości, a jeśli zajdziecie w ciążę, to tym lepiej. Oddajecie przysługę ojczyźnie. Jeżeli się to wam przydarzy, w żadnym wypadku nie powiadamiajcie rodziców, dobrze się z tym ukrywajcie i zwróćcie się do mnie, a ja wam doradzę, w jaki sposób natychmiast po urodzeniu pozbyć się noworodka: zajmie się nim państwo (Ducret 2012: 273).

Niedługo sierocińce w całym kraju pękały w szwach.

Agnieszka Graff zwróciła uwagę na ścisły związek pomiędzy zakazem aborcji a systemami totalitarnymi. Jej zdaniem odebranie kobietom prawa do aborcji mieści się w plemiennej wizji narodu, zgodnie z którą kobiety dla dobra wspólnoty mają rodzić jej nowych członków, a mężczyźni - zabijać członków innych plemion. Graff uważa, że w ideologii totalitaryzmu wartością absolutną nie jest życie człowieka narodzonego czy nienarodzonego, ale potęga plemienia lub narodu wyrażająca się w jego liczebności (Graff 2001: 133-134).

\section{Prawo aborcyjne w Polsce}

Prawo aborcyjne określające zakres sytuacji uprawniających do przerwania ciąży zmieniało się w Polsce kilkakrotnie. Na przełomie lat dwudziestych i trzydziestych XX wieku toczyła się debata dotycząca zmiany prawa antyaborcyjnego. Prawa do przerwania ciąży dla wszystkich kobiet (niezależnie od podziałów klasowych i sytuacji ekonomicznej rodziny) domagali się między innymi: Maria Pawlikowska-Jasnorzewska, Irena Krzywicka i Tadeusz Boy-Żeleński, autor najważniejszego manifestu feministycznego lat międzywojennych (Boy-Żeleński 2013). Wszyscy oni dostrzegli, że podtrzymywany przez państwo całkowity zakaz aborcji ma na celu zapewnienie sukcesu militarnego w ewentualnej wojnie.

Irena Krzywicka - polska feministka, pisarka, tłumaczka i publicystka w 1937 roku na łamach "Życia Świadomego" napisała:

Gdzie tam, to wspólna wszystkim dyktaturom żądza ludzkiego mięsa, choćby w najgorszym gatunku, choćby stoczonego przez choroby i głód. To jawny lub utajony militaryzm 
tak się przejawia. Żołnierzy! Jak najwięcej żołnierzy [...]. Hasło rodzenia to zapowiedź wojny! (Krzywicka 1937 cyt. za: Zaremba-Bielawski 2011: 352).

Z kolei Boy-Żeleński w Piekle kobiet napisał: „, [...] hasło nieograniczonego płodzenia to imperializm, to odwet, to przyszła wojna. Dzień, w którym kobieta polska porozumiałaby się z niemiecką co do «demobilizacji macic», byłby ważnym dniem dla pokoju ludzkości" (Boy-Żeleński 2013: 96).

Dnia 11 lipca 1932 roku uchwalono rozporządzenie, które uchylało całkowity zakaz aborcji obowiązujący w czasie zaborów. Zalegalizowano przerwanie ciąży powstałej w wyniku kazirodztwa, gwałtu lub współżycia z nieletnią poniżej piętnastego roku życia oraz z przyczyn medycznych. Było to jedno z najbardziej liberalnych rozwiązań w Europie.

Podczas okupacji niemieckiej, w latach 1943-1945 kobiety w Polsce miały jak dotąd pierwszy i ostatni raz prawo do aborcji „na życzenie”. Ustawa z dnia 27 kwietnia 1956 roku zezwalała na przerwanie ciąży, gdy przemawiały za tym wskazania lekarskie, trudne warunki życiowe oraz gdy zachodziło podejrzenie, że ciąża powstała wskutek przestępstwa (w praktyce na życzenie kobiety) (CBOS 2013).

W latach dziewięćdziesiątych prawodawstwo uległo zaostrzeniu. Prawo aborcyjne reguluje ustawa z dnia 7 stycznia 1993 roku o planowaniu rodziny, ochronie płodu ludzkiego i warunkach dopuszczalności przerwania ciąży (Dz. U. Nr 17, poz. 78 ze zm.). Zgodnie $\mathrm{z}$ art. 4a przerwanie ciąży jest dozwolone w czterech przypadkach:

1. gdy ciąża stanowi zagrożenie dla życia lub zdrowia kobiety ciężarnej (co musi stwierdzić inny lekarz niż dokonujący zabieg);

2. badania prenatalne lub inne przesłanki medyczne wskazują na duże prawdopodobieństwo ciężkiego i nieodwracalnego upośledzenia płodu albo nieuleczalnej choroby zagrażającej jego życiu (co również stwierdza inny lekarz niż dokonujący przerwania ciąży);

3. zachodzi uzasadnione podejrzenie, że ciąża powstała w wyniku czynu zabronionego (gwałt, kazirodztwo);

4. kobieta ciężarna znajduje się w ciężkich warunkach życiowych lub trudnej sytuacji osobistej.

W pierwszym przypadku przerwanie ciąży jest dozwolone do dwunastego tygodnia ciąży. W dwóch pozostałych prawo do tego zabiegu przysługuje aż do momentu osiągnięcia przez płód zdolności do samodzielnego życia poza organizmem kobiety. Punkt czwarty ustawy, umożliwiający przerwanie ciąży, gdy kobieta ciężarna znajduje się w ciężkich warunkach życiowych lub trudnej sytuacji osobistej (Szczuka 2004: 8), utracił moc 18 grudnia 1997 roku na podstawie obwieszczenia Prezesa Trybunału Konstytucyjnego z dnia 18 grudnia 1997 r. o utracie mocy obowiązującej art. 1 pkt 2 , art. 1 pkt 5 , art. 2 pkt 2 , art. 3 pkt 1 i art. 3 pkt 4 ustawy o zmianie ustawy o planowaniu rodziny, ochrony płodu ludzkiego i warunkach dopuszczalności przerywania ciąży oraz o zmianie niektórych innych ustaw (Dz. U. $\mathrm{Nr} 157$, poz. 1040), uznającego go za sprzeczny z konstytucją. 
W kwestii prawa kobiet do aborcji jednak wiele zależy od lekarzy, ponieważ nie powstała do tej pory lista wad i upośledzeń, które byłyby podstawą do wykonania zabiegu. Na ogół jeden lekarz odsyła ciężarną do drugiego, a drugi do trzeciego (Święchowicz 2014: 26).

W sierpniu 2016 roku do Sejmu trafił projekt liberalizacji prawa aborcyjnego złożony przez inicjatywę „Ratujmy Kobiety”, który zakładał między innymi prawo do przerwania ciąży do końca dwunastego tygodnia, edukację seksualną oraz refundacje środków antykoncepcyjnych. Dnia 23 września, po pierwszym czytaniu, projekt został odrzucony (Wprost 2016). Z kolei w lipcu do Sejmu trafił inny obywatelski projekt ustawy "Stop aborcji” o zmianie ustawy z dnia 7 stycznia 1993 r. o planowaniu rodziny, ochronie płodu ludzkiego i warunkach dopuszczalności przerwania ciąży oraz ustawy z dnia 6 czerwca 1997 r. ${ }^{3}$, przygotowany przez stowarzyszenie Ordo luris. Przewidywano w nim między innymi możliwość karania kobiet, które poddałby się aborcji (od trzech miesięcy do pięciu lat pozbawienia wolności) (Newsweek 2016). Należy dodać, że w treści omawianej propozycji projektu antyaborcyjnego znalazł się także zapis, według którego sąd mógłby nadzwyczajnie złagodzić karę lub odstąpić od jej wymierzenia w przypadku, gdy matka „dziecka poczętego” działałaby nieumyślnie.

Dnia 3 października 2016 roku odbył się Ogólnopolski Strajk Kobiet, to znaczy „Czarny Protest". Tysiące kobiet nie poszło tego dnia do pracy, aby wyjść na ulicę i wyrazić sprzeciw wobec pomysłu zaostrzenia prawa aborcyjnego. Dnia 6 października projekt „Stop aborcji” został odrzucony przez Sejm (ts/kk 2016).

Klub partii Prawa i Sprawiedliwości przygotowuje obecnie projekt dotyczący przepisów regulujących aborcję. Z pewnością będzie dążyło się do ograniczenia przerwań ciąży o charakterze eugenicznym (posłowie i posłanki najczęściej odwołują się do przypadków dzieci z zespołem Downa). Dokładniejszych informacji nie podano (p.mal 2016). W internecie pojawiają się także informacje o projekcie Polskiej Federacji Ruchów Obrony Życia, który trafił 6 października do Marszałka Sejmu w formie petycji. W dokumencie przewiduje się całkowity zakaz aborcji, odstąpiono jednak od pomysłu karania kobiet za jej dokonanie. Nowymi postulatami są między innymi zakaz sprzedaży środków o działaniu poronnym i antyimplantacyjnym oraz obowiązek objęcia przez państwo instytucjonalnej opieki rodziny, samotnych rodziców dzieci niepełnosprawnych oraz matek i dzieci, kiedy dojdzie do tak zwanego czynu zabronionego (gwałt) (ds 2016).

\section{Metoda interpretacji materiału empirycznego - krytyczna analiza dyskursu}

Materiał empiryczny został zinterpretowany przy użyciu krytycznej analizy dyskursu. Odnosi się ona do obszaru współczesnego językoznawstwa, w którym od pół wieku wyraźnie oddziela się badania nad strukturą języka (lingwistyka

3 Treść projektu dostępna jest na stronie internetowej: http://www.stopaborcji.pl/wp-content/ uploads/2016/03/projekt_2016.pdf [dostęp: 16.10.2016]. 
formalna) oraz badania języka w użyciu (język jako narzędzie komunikacji). Na gruncie współczesnego językoznawstwa dużym zainteresowaniem cieszą się takie nurty jak pragmatyka językowa (George P. Lakoff) czy socjolingwistyka (Basil Bernstein). Jak podkreśla Norman Fairclough, zaletą tych analiz jest badanie języka w kontekście społecznych funkcji (Duszak, Fairclough 2008: 12). W naukach społecznych jest potrzebna analiza sposobów używania języka, ponieważ zjawiska społeczne są punktem przecięcia tego, co dyskursywne i niedyskursywne. Fairclough zauważa, że analiza zmian społecznych bez analizy ich językowej warstwy i relacji dyskursywne-niedyskursywne jest zawsze niepełna, niekompletna (Duszak, Fairclough 2008: 10).

Fairclough definiuje krytyczną analizę dyskursu jako formę krytycznych badań społecznych, które analizują relacje między kategoriami myślenia - wiedzą, wartościami, wyobrażeniami - a innymi elementami systemów społecznych i procesów, celem ustalenia, w jaki sposób "cementowanie" tych pierwszych w tych drugich przyczynia się do powstania, trwania lub zmiany $\mathrm{w}$ obrębie relacji społecznych stosunków władzy, ideologii, dominacji, hegemonii, marginalizacji czy opresji (Duszak, Fairclough 2008). Krytyczna analiza dyskursu umożliwia analizę relacji łączących sferę znaczeń (dyskursu) i materialności (sfery niedyskursywnej).

Chris Barker twierdzi z kolei, że dyskursy dostarczają sposobów mówienia o danym zjawisku, temacie czy problemie dzięki powtarzalnym zbiorom idei, praktyk, rodzajów wiedzy i motywom, które się do nich odnoszą (Barker 2005: 115). Dyskurs można określić mianem względnie trwałej mapy znaczeń lub sposobów mówienia, dzięki którym przedmioty lub praktyki nabierają znaczenia. Jak twierdzą znawcy krytycznej analizy dyskursu, uporządkowanie znaczenia jest następstwem wpływu wywieranego przez władzę na obszar praktyki społecznej. W związku z tym dyskurs jest traktowany jako element "jednoczący” język i praktykę (Barker 2005).

Krytyczna analiza dyskursu wydaje się interesująca z tego względu, że jej praktykowanie nie oznacza konieczności pozostawania poza ramami teoretycznymi w procesie konstruowania przedmiotu badań. Według Davida Howartha osadzenie badań w określonych ramach teoretycznych oznacza jedynie, że mamy do czynienia z polem otwartym, elastycznym i gotowym do reorganizacji w trakcie analiz (Howarth 2008: 214).

Opisując współczesny obraz prawa kobiet do zabiegu przerwania ciąży $\mathrm{w}$ przestrzeni medialnej, skupiono się na analizie języka wybranych stron funkcjonujących na portalu społecznościowym Facebook. Celem analizy była próba rekonstrukcji powtarzalnych obrazów prawa kobiet do aborcji, wspólnych wzorów reagowania na nie oraz wspólnych sfer artykułowanych znaczeń (sposobów widzenia, ocen). W ramach tego serwisu użytkownicy mogą tworzyć własne sieci, grupy oraz - co najistotniejsze - wymieniać się poglądami na wybrane tematy (także na temat prawa kobiet do aborcji). 


\section{Współczesny obraz prawa do aborcji w przestrzeni medialnej}

Obecnie w medialnej debacie na temat prawa kobiet do aborcji można dostrzec dwie orientacje: pro-life (przeciwnicy prawa kobiet do aborcji) oraz pro-choice (zwolennicy legalizacji zabiegu przerwania ciąży i praw reprodukcyjnych). Biorą w niej udział zarówno księża, jak i profesorowie, etycy, publicyści i feministki. Wśród najbardziej rozpoznawalnych osób, które od wielu lat uczestniczą w tej dyskusji, należy wymienić: Agnieszkę Graff, Wandę Nowicką, Kazimierę Szczukę i Magdalenę Środę (pro-choice) oraz Bogdana Chazana, Kaję Godek i Tomasza Terlikowskiego (pro-life).

Na początku przeanalizowano treści dotyczące aborcji oraz komentarze użytkowników, które pojawiły się na dwóch profilach utworzonych przez osoby biorące aktywny udział w sporze dotyczącym liberalizacji obecnego prawa aborcyjnego. Pierwszym był profil utworzony przez Kazimierę Szczukę - działaczkę społeczną, feministkę, współzałożycielkę Kongresu Kobiet. Dnia 4 lutego 2015 roku Szczuka udostępniła na swojej stronie wywiad z dr. med. Januszem Rudzińskim - lekarzem ginekologiem, pracującym w klinice w Prenzlau (Niemcy), który wykonuje zabiegi przerwania ciąży (także na życzenie przyjeżdżających zza granicy Polek). W wywiadzie Rudziński opowiadał między innymi, jak wygląda zabieg aborcyjny, ile trwa oraz co niemieccy lekarze sądzą o klauzuli sumienia. Pod udostępnionym przez dziennikarkę materiałem pojawiły się liczne komentarze. Oto niektóre z nich, pochodzące z profilu Kazimiery Szczuki

Mordercy.

Jak można okrutne morderstwo z premedytacją nazwać „małym, krótkim zabiegiem” ... Brrr.

Tak zapewne ten wykonywany w późnym etapie życia prenatalnego dziecka. Brak słów w tak żałosny sposób usprawiedliwiać zabijanie dzieci...

Szkoda, że aborcji nie było wcześniej. Bo gdyby były rodzice PO i żydokomuny i SLD miało taką aborcje, to nie socjalizmu i głupiej Kazi i głupich tematów na temat równouprawnienia i tematów aborcji. Ponieważ ten temat wymarłby śmiercią naturalną.

PS. Aborcja $=$ Morderstwo.

To morderstwo. Zabija się szybko (Facebook: Kazimiera Szczuka 2015).

We wszystkich komentarzach pojawiło się słowo „morderstwo” - każdy z cytowanych użytkowników utożsamił zabieg przerwania ciąży z zabójstwem dziecka, okrutnym, dokonanym z premedytacją. Internautów zszokowało stwierdzenie lekarza, że aborcja to krótki zabieg. Co ciekawe, jeden z komentujących (deklarujący się raczej jako przeciwnik aborcji) upatrywał w niej szansę zapobiegania powstania niektórych partii politycznych (PO, SLD), a także takich problemów społecznych jak

${ }^{4}$ Wyróżnienia w cytatach - A.B. Wypowiedzi zostały przywołane w oryginalnym brzmieniu i z oryginalną pisownią. 
równouprawnienie czy prawo do aborcji (poprzez aborcję konkretnych polityków i działaczy społecznych, w tym Kazimiery Szczuki).

Druga z kolei analizowana treść dotycząca prawa kobiet do aborcji pochodziła z profilu Tomasza Terlikowskiego - dziennikarza, publicysty katolickiego, redaktora naczelnego portalu Fronda.pl i Telewizji Republika. Dnia 1 maja 2015 roku, po ogłoszeniu wyroku uniewinniającego w sprawie profesora Bogdana Chazana, Terlikowski w poście umieszczonym na swojej stronie domagał się między innymi publicznych przeprosin profesora, który odmówił pacjentce wykonania legalnej aborcji uszkodzonego płodu, powołując się na klauzulę sumienia:

Medialny i polityczny lincz jakiego dokonano na bohaterskim ginekologu, który odmówił zabicia dziecka, tylko dlatego, że było ono niepełnosprawne, zakończył się sukcesem aborcjonistów. Prof. Bogdan Chazan, wbrew zdrowemu rozsądkowi i polskiemu prawu został nie tylko oczerniony, ale też zwolniony z pracy. Kolejne decyzje prokuratury pokazują zaś obecnie, że to właśnie jego zwolnienie było bezprawne, a lincz był klasycznym przykładem gangsterskiego zastraszenia. Jeśli więc Hanna Gronkiewicz-Waltz chce zachować minimum honoru czy wiarygodności, to powinna nie tylko publicznie (tak, tak) przeprosić prof. Chazana, ale też błyskawicznie przywrócić go do pracy na stanowisku dyrektora szpitala. Jeśli tego nie zrobi pokaże - nie po raz pierwszy zresztą - że jej działania są jawnie antykatolickie, i że z jej dawnego zaangażowania nic już nie zostało. Jeśli bowiem profesor był niewinny, to jedynym powodem zwolnienia go z pracy była jego wiara, której nie była w stanie zaakceptować rzekomo wierząca Hanna Gronkiewicz-Waltz (Facebook: Tomasz P. Terlikowski 2015).

Terlikowski zabieg przerwania ciąży konsekwentnie nazywał „zabijaniem dziecka". Przeciwników prawa kobiet do aborcji określił jako tych, którzy kierują się zdrowym rozsądkiem, a przyczyn zwolnienia profesora Chazana doszukiwał się w antykatolickim stosunku władzy do wiary lekarza.

Pod napisanym przez dziennikarza postem znalazły się różnorodne komentarze:

Nie istnieje coś takiego jak podmiotowe prawo do aborcji. Jest prawo do życia (Facebook: Tomasz P. Terlikowski 2015).

Niektórzy internauci negowali prawo kobiet do aborcji, ich zdaniem ono po prostu nie istnieje. Agnieszka Graff w swoim felietonie stwierdziła, że słowo „życie” to słowo ciężkiego kalibru, które odnosi się do wartości absolutnej. Jej zdaniem wobec tyranii tego słowa bledną inne - takie jak "wybór", "świadoma decyzja”, „odpowiedzialność”, „wolność" (Graff 2001: 120).

Kolejny cytat ponownie utożsamiał aborcję z „cywilizacją śmierci”:

Zabijanie chorych to ciekawy pomysl. Wlasnie zdiagnozowano u pana katar. Prosze podac adres, nasze sluzby medyczne juz po pana jada (Facebook: Tomasz P. Terlikowski 2015).

Internauta określił aborcję jako zabijanie chorych (niewinnych), przy czym, co ciekawe, zbagatelizował problemy, jakimi są ciężkie uszkodzenia płodu, porównując je do kataru (czyli objawu najczęściej niegroźnej infekcji, którą można 
wyleczyć różnorodnymi środkami farmakologicznymi - w przeciwieństwie do wad wrodzonych).

Pojawiły się także niejednoznaczne w swojej treści komentarze oceniające postępowanie lekarza, który odmówił pacjentce prawa do legalnej aborcji:

Generalnie chodzi o to że zasłaniając się sumieniem można łamać prawo, w takim razie ja przestaję płacić podatki bo moje sumienie mi na to nie pozwala. Ciekawe jak wtedy sie skończy sprawa (Facebook: Tomasz P. Terlikowski 2015).

Użytkownik Facebooka zwrócił uwagę, że postępowanie profesora było niezgodne z obowiązującym prawem antyaborcyjnym. Jego porównanie prawa do aborcji z obowiązkiem płacenia podatków przez obywateli wydaje się jednak niesłuszne. Można stwierdzić, że internauta wykazał się ignorancją w stosunku do istniejącego problemu społecznego, jakim jest ograniczanie kobietom dostępności do zabiegu przerwania ciąży, chociaż zgodnie z obowiązującą (restrykcyjną) ustawą mają do niego prawo.

Z kolei użytkowniczki portalu społecznościowego, jako jedyne, zwracały uwage na postać kobiety w poruszanej kwestii. Podkreślały znaczenie jej sumienia i decyzji o przerwaniu bądź kontynuowaniu ciąży oraz na cierpienie towarzyszące zarówno jej, jak i nowonarodzonemu dziecku z ciężką wadą wrodzoną:

Lepiej przecież zmuszać matkę do patrzenia, jak jej dziecko z tak okropną przypadłością umiera tygodniami podłączone do maszyny. Jakby się je jeszcze zdążyło ochrzcić i wpisać do ksiąg Kościoła to byłby pełny sukces. Bezmózgowie to nie Zespół Downa, Panie Terlikowski. Nie mówimy tu o niepełnosprawności, a o nieuleczalnej i śmiertelnej wadzie wrodzonej (Facebook: Tomasz P. Terlikowski 2015).

Przerwanie tej ciąży powinno być kwestią sumienia matki dziecka a nie lekarza który ją prowadził. Odmawiając złamał prawo i naraził matkę jak i dziecko na straszne cierpienie. Powinien dla przykładu pójść pierdzieć w pasiak. Mam jednak nadzieję, że w żadnym publicznym ośrodku zdrowia nie dostanie pracy (Facebook: Tomasz P. Terlikowski 2015).

W przestrzeni medialnej, którą tworzy między innymi portal Facebook, można śledzić nie tylko profile osób udostępniających treści dotyczące aborcji, ale także liczne strony, na których użytkownicy mogą wyrażać swoje poglądy na temat prawa kobiet do zabiegu przerwania ciąży. Wśród stron o charakterze pro-life znalazły się między innymi: Aborcja to zabijanie dzieci (2015), Aborcja to zbrodnia (2015), Fundacja Pro - Prawo do Życia (2015), KObiety Przeciwko Aborcji (KOPA) (2015) czy Popieram profesora Chazana (2015). Na tablicach wszystkich wyżej wymienionych stron bardzo często pojawiały się zdjęcia rozczłonkowanych, martwych płodów, uśmiechniętych bądź przerażonych dzieci z zespołem Downa (z podpisem „ratuj nas") czy doktora Mengele z informacją, jakoby po ucieczce z Europy praktykował w Argentynie jako aborter. Pod postami użytkownicy opisywali na przykład czym ich zdaniem - jest zabieg aborcji i kim są kobiety, które się na niego zdecydowały: 


\section{Morderstwa, ludobójstwo, dzieciobojstwo.}

\section{Hitlerowcy.}

holokaust 21 wieku (Facebook: Fundacja Pro - Prawo do życia 2015).

Aborcję ponownie nazwano morderstwem, odwołując się tym razem do historii Holocaustu oraz określając terminację ciąży jako praktykę hitlerowską lub rasistowską. Jak napisała Agnieszka Graff, rzecz w tym, że wymordowani przez nazistów Żydzi nie byli płodami, lecz ludźmi, którzy posiadali nie tylko świadomość, myśli i uczucia, ale także język i historię. Ta kontrowersyjna metafora działa dopiero wówczas, gdy w pełni przyjmie się teologiczną definicję człowieka jako bytu, który ma duszę od poczęcia, gdy unieważni się wszystko to, co dzieli płód od dziecka (Graff 2001:133).

Masakra Aborcja to mordowanie najgorsze jest to ze mordowanie malutkich nowonarodzonych dzieci.... tylko Bóg może dać i odebrać życie..m żaden z ludzi nie ma do tego prawa!!!! (Facebook: Fundacja Pro - Prawo do życia 2015)

W tym komentarzu pojawia się retoryka katolicka, według której tylko Bóg może decydować o narodzinach i śmierci człowieka. Co ciekawe, internautka określiła aborcję jako mordowanie nowonarodzonych dzieci. Nie wiadomo, czy to celowa manipulacja semantyczna, czy przejaw ignorancji lub braku wiedzy ze strony komentującej, gdyż - jak wiadomo - aborcja to zabieg usunięcia płodu (czyli w okresie prenatalnym), a nie zabójstwo noworodka.

Inne komentarze koncentrowały się na krytykowaniu kobiet, które deklarują swoje stanowisko w sporze o prawo do aborcji jako pro-choice:

Jak slysze takie glupie szczeniackie wypowiedzi typu kobieta jej cialo jej wybor, to mi az niedobrze sie robi. Owszem ma wybor zabezpieczac sie a nie mordowac niewinne bejbiki! (Facebook: Fundacja Pro - Prawo do życia 2015)

Fakt są kobiety, dla których własna wygoda,jest o wiele ważniehsza niż małeńki człowiek rosnący pod ich sercem i dla tej wygody gotowe są nawet zabić smutne to ale prawdziwe (Facebook: KObiety Przeciwko Aborcji [KOPA] 2015).

Internautki (deklarujące się po stronie pro-life) przerzucają odpowiedzialność za niechcianą ciążę na kobietę, twierdząc, że jej obowiązkiem jest zabezpieczanie się. Z kolei zabieg przerwania ciąży ponownie określają jako mordowanie niewinnych dzieci („bejbików”), wygodę i „szczeniackie” (nieodpowiedzialne) działanie.

Na Facebooku istnieją także strony o charakterze pro-choice, są to na przykład: Aborcja prawem kobiet (2015), Prawo wyboru jest dobrem osobistym (2014), TAK! Dla legalnej aborcji w Polsce (2015) czy Masz prawo przerwać ciążę? Możesz to zrobić zagranicą na koszt NFZ (2015). Na stronach tych - podobnie jak na stronach o charakterze pro-life - bardzo ważną rolę odgrywają obrazy. Można zobaczyć na nich między innymi przekreślony wieszak (symbol aborcji wykonywanej w podziemiu, bardzo często kończącej się okaleczeniem bądź śmiercią kobiet), znak nierówności pomiędzy rysunkiem kobiety a żeńskim układem rozrodczym 
(manifestującym, że jedyną rolą kobiety nie jest rola matki, „reproduktorki” narodu) czy wizerunek Tadeusza Boya-Żeleńskiego wraz z cytatem pochodzącym ze zbioru felietonów Piekło kobiet jego autorstwa:

Głosić wzniosłe teorie o „prawie płodu do życia”, znów grozić matce więzieniem w imię praw tego płodu, ale równocześnie nie troszczyć się o to, aby nosicielka tego płodu miała co do ust włożyć... I rzecz szczególna, ten sam płód, nad którym trzęsą się ustawodawcy, póki jest w łonie matki, w godzinę po urodzeniu traci wszelkie prawa do opieki prawnej, może zginąć pod mostem z zimna, gdy matka - którą jej „święte" macierzyństwo czyni nieraz wyrzutkiem społeczeństwa - nie ma dachu nad głową (Boy-Żeleński 2013: 10).

Użytkownicy komentowali udostępniane posty, najczęściej opisując zabieg przerwania ciąży w kategoriach indywidualnej sprawy kobiety, natomiast obowiązujące prawo aborcyjne określali mianem zniewolenia i przymusu:

aborcja to decyzja kazdej kobiety ja ja popieram gdyz lepiej usunac zarodek niz wyrzucic do smieci urodzonego noworotka...

Internautka w wyżej przytoczonym cytacie wyraźnie rozróżnia zarodek od noworodka, podkreślając, że aborcja jest kwestią związaną z decyzją kobiety. Zwróciła uwagę na ostatnio nagłaśniany w mediach problem społeczny jakim jest dzieciobójstwo.

Pojawiły się także bardziej kontrowersyjne komentarze, które określały płód jako „coś niechcianego”. Co ważne, użytkowniczka portalu Facebook dostrzegła, że nieplanowane macierzyństwo (niechciane) może stać się męką (problemem) dla kobiety:

lepiej usunąć coś niechcianego niż się męczyć całą resztę życia.

Interanutki (deklarujące się po stronie pro-choice) nazywały aborcję przerwaniem ciąży, konsekwencją indywidualnego wyboru każdej kobiety, podkreślając przy tym sposób, w jaki kobiety traktowane są przez państwo (zniewolenie i przymus):

Każdy powinien mieć prawo wyboru. Każda kobieta powinna mieć możliwość przerwania ciąży do 12 tygodnia w bezpiecznych warunkach. Czy z tej wolności skorzysta, to już sprawa indywidualna. A to co robi rząd i co dalej chce robić...To jest zniewolenie i przymus!

Myślę, że to idywidualna sprawa każdego człowieka, jego sumienia, jego światopoglądu. Mieć do czegoś prawo, nie znaczy mieć przymus stosowania tego. Ja chcę żyć w wolnym kraju w którym sam mam prawo podejmowania pewnych decyzji. Może za chwilę ktoś wpadnie na pomysł zakazu wycierania nosa. Bo przy tym niszczy się więcej ludzkiej tkanki niż przy in vitro.

Aborcja jest wyborem, w zyciu sa trudne i bardziej trudne sytuacje, kazdy powinien miec dostep do wszystkim mozliwych rozwiazan i korzystac z nich wedlug swoich przekonan... 
Realia sa takie, ze kobieta z plodem z wada genetyczna jest zmuszana do noszenia ciazy do 20., 21. tygodnia (bo tyle czasu czeka sie na wyniki testow), a potem "aborcja” ruszajacego sie juz plodu to wymuszony przedwczesny porod. I to jest humanitarne wobec kobiety???

\section{Jak mówimy o aborcji?}

Problem społeczny prawa kobiet do aborcji jest kwestią kontrowersyjną i delikatną zarazem. Według danych podawanych przez CBOS zdania Polaków na temat aborcji są podzielone:

Co drugi dorosły Polak (50\%) sprzeciwia się prawu do aborcji, jednak za całkowitym zakazem przerwania ciąży jest co siódmy respondent (14\%), a ponad jedna trzecia ankietowanych $(36 \%)$ twierdzi, że powinny być od niego wyjątki. Jednocześnie prawie połowa badanych (45\%) uważa, że aborcja powinna być dozwolona. W tej grupie $7 \%$ pytanych deklaruje swoje poparcie dla przerywania ciąży bez żadnych ograniczeń, a 38\% opowiada się za pewnymi ograniczeniami (CBOS 2010).

Jak można zauważyć, na podstawie wcześniej przytoczonych komentarzy, które pojawiały się zarówno pod postami udostępnianymi przez Kazimierę Szczukę czy Tomasza Terlikowskiego, jak również na stronach o charakterze pro-life i pro-choice, język obu środowisk opisujący aborcję diametralnie się różni. Przeciwnicy prawa kobiet do aborcji definiują tę kwestię jako morderstwo, ludobójstwo, dzieciobójstwo a nawet Holocaust. Z kolei zwolennicy legalizacji aborcji traktują ją jako zabieg przerwania ciąży i opisują ją w kategoriach decyzji, prawa wyboru czy indywidualnej sprawy każdej kobiety. Oba środowiska w odmienny sposób określają także byt, który rozwija się w łonie kobiety - dla prolajfowców ten byt jest dzieckiem, maleńkim człowiekiem, natomiast zdaniem ich oponentów to zarodek lub płód, w zależności od zaawansowania ciąży. Bardzo często w komentarzach użytkownicy stron pro-life przywoływali postać Boga, który jako jedyny może dać i odebrać życie człowiekowi. Użytkownicy stron pro-choice z kolei uważali, że prawo boskie (wyznaniowe) nie może stać ponad prawem świeckim. Obowiązujące w Polsce prawo aborcyjne, które należy do jednego z najbardziej restrykcyjnych w Europie, również jest pojmowane w odmiennych kategoriach. Zdaniem zwolenników zaostrzenia ustawy antyaborcyjnej jest ono dla kobiet wygodne, natomiast dla ich adwersarzy stanowi ono przymus do bycia w niechcianej ciąży i rodzenia nieplanowanych dzieci.

Tabela 1. Wybrane słowa definiujące aborcję przez środowiska pro-life i przez środowiska pro-choice

\begin{tabular}{|l|l|}
\hline \multicolumn{1}{|c|}{ Pro-life } & \multicolumn{1}{|c|}{ Pro-choice } \\
\hline morderstwo & decyzja \\
\hline ludobójstwo & prawo wyboru \\
\hline dzieciobójstwo & przerwanie ciąży \\
\hline
\end{tabular}




\begin{tabular}{|l|l|}
\hline \multicolumn{1}{|c|}{ Pro-life } & \multicolumn{1}{c|}{ Pro-choice } \\
\hline Holocaust & indywidualna sprawa \\
\hline dziecko & płód \\
\hline maleńki człowiek & zarodek \\
\hline Bóg & Prawo \\
\hline wygoda & przymus \\
\hline
\end{tabular}

Źródło: opracowanie własne

Reasumując, niejednoznaczne, niejasne i pełne sprzeczności słowa definiujące aborcję w przestrzeni medialnej tworzą językowe „piekło kobiet”. Ambiwalencja języka wynika z niemożliwości przyrównywania definicji aborcji proponowanej przez środowiska pro-life $z$ definicjami proponowanymi przez środowiska pro-choice, na przykład morderstwo-decyzja, ludobójstwo-prawo wyboru, wygodaprzymus.

Ponad dziesięć lat temu Agnieszka Graff stwierdziła, że nie da się rozmawiać, gdy każda ze stron definiuje istotę debaty w innych kategoriach. Z punktu widzenia zwolenników prawa kobiety do wyboru „człowieczeństwo od poczęcia” to absurd, chwyt retoryczny, narzędzie szantażu emocjonalnego. Przywołując myśl Bożeny Umińskiej, Graff podkreśliła, że problem nie do przekroczenia leży w różnicy postaw, mentalności i takim definiowaniu człowieka, że między zapłodnioną ludzką komórką, płodem, noworodkiem i dorosłym człowiekiem nie ma różnicy. To, co dla jednych jest prawem do osobistej wolności, dla innych jest morderstwem (Graff 2001: 114).

Dlatego udzielenie odpowiedzi na pytanie, czy współczesny obraz prawa kobiet do aborcji w przestrzeni medialnej jest casusem ich zniewolenia czy emancypacji jest zadaniem trudnym. Zapewne jeszcze długo pozostanie bez jednoznacznej odpowiedzi.

\section{Literatura:}

Barker C., 2005, Studia kulturowe. Teoria i praktyka, tłum. A. Sadza, Kraków: Wydawnictwo Uniwersytetu Jagiellońskiego.

Boy-Żeleński T., 2013, Piekło kobiet, oprac. D. Kowalska, M. Niedziałkowska, P. Rzymanek, Warszawa: Jirafa Roja.

CBOS, 2010, Dopuszczalność aborcji w różnych sytuacjach. Komunikat z badań nr 71/2016, http:// www.cbos.pl/SPISKOM.POL/2016/K_071_16.PDF [dostęp: 13.10.2016].

CBOS, 2013, Doświadczenia aborcyjne Polek. Komunikat z badańBS/60/2013, http://www.cbos.pl/ SPISKOM.POL/2013/K_060_13.PDF [dostęp: 13.10.2016].

ds, 2016, Nowy projekt ustawy antyaborcyjnej! Zakazuje aborcji i nie karze kobiet, http://telewizjarepublika.pl/nowy-projekt-ustawy-antyaborcyjnej-zakazuje-aborcji-i-nie-karze-kobiet,38930.html [dostęp: 13.10.2016].

Ducret D., 2012, Kobiety dyktatorów, tłum. M. Rostworowska, Kraków: Wydawnictwo Znak.

Duszak A., Fairclough N., 2008, Wstęp. Krytyczna analiza dyskursu - nowy obszar badawczy dla lingwistyki i nauk spotecznych [w:] Krytyczna analiza dyskursu. Interdyscyplinarne podejście 
do komunikacji społecznej, red. A. Duszak, N. Fairclough, Kraków: Towarzystwo Autorów i Wydawców Prac Naukowych „Universitas”.

Facebook: Aborcja prawem kobiet, 2015, https://www.facebook.com/AborcjaPrawemKobiet?ref $=$ ts\&fref $=$ ts [dostęp: 20.04.2015].

Facebook: Aborcja to zabijanie dzieci, 2015, https://www.facebook.com/aborcjatozabijanie?fref =ts [dostęp: 18.04.2015].

Facebook: Aborcja to zbrodnia, 2015, https://www.facebook.com/aborcjatozbrodnia?fref $=$ ts [dostęp: 18.04.2015].

Facebook: Fundacja Pro - Prawo do Życia, 2015, https://www.facebook.com/FundacjaPro? fref $=$ ts [dostęp: 19.04.2015].

Facebook: Kazimiera Szczuka, 2015, https://www.facebook.com/KaziaSzczuka?fref=ts [dostęp: 17.04.2015].

Facebook: KObiety Przeciwko Aborcji (KOPA), 2015, https://www.facebook.com/KobietyPrzeciwkoAborcji?fref =ts [dostęp: 19.04.2015].

Facebook: Masz prawo przerwać ciążę? Możesz to zrobić zagranicą na koszt NFZ, 2015, https:// www.facebook.com/pages/Masz-prawo-przerwa\%C4\% 87-ci\% C4\% 85\% C5\% BC\% C4\% 99 -Mo\% C5\% BCesz-to-zrobi\% C4\% 87-zagranic\% C4\% 85-na-koszt-NFZ/189253997792958? fref $=$ ts [dostęp: 20.04 .2015$]$.

Facebook: Popieram profesora Chazana, 2015, https://www.facebook.com/popieramprofesora?fref =pb\&hc_location=profile_browser [dostęp: 18.04.2015].

Facebook: Prawo wyboru jest dobrem osobistym, 2014, https://www.facebook.com/PrawoWyboru?fref $=$ pb\&hc_location $=$ profile_browser [dostęp: 20.04 .2014$]$.

Facebook: TAK! Dla legalnej aborcji w Polsce, 2015, https://www.facebook.com/TakDlaLegalnejAborcjiWPolsce?ref $=$ ts\&fref $=$ ts [dostęp: 20.04 .2015$]$.

Facebook: Tomasz P. Terlikowski, 2015, https://www.facebook.com/pages/Tomasz-P-Terlikowski/227951087237218?fref=ts [dostęp: 3.05.2015].

Gawlicz K., 2005, Płeć i naród. Dyskurs dotyczący aborcji w "Naszym Dzienniku” a konstruowanie tożsamości narodowej [w:] Kobiety, feminizm, media red. E. Zierkiewicz, I. Kowalczyk, Poznań-Wrocław: Konsola.

Graff A., 2001, Świat bez kobiet. Płeć w polskim życiu publicznym, Warszawa: W.A.B.

Howarth D., 2008, Dyskurs, tłum. A. Gąsior-Niemiec, Warszawa: Oficyna Naukowa.

Matuchniak-Krasuska A., 1995, Czym była dyskusja o aborcji [w:] Co to znaczy być kobieta w Polsce. Praca zbiorowa, red. A. Titkow, H. Domański, Warszawa: Wydawnictwo IFiS PAN.

Newsweek, 2016, Projekt antyaborcyjny w całości odrzucony. Kaczyński radzit posłom "ochtonać", http://www.newsweek.pl/polska/projekt-ustawy-aborcyjnej-odrzucony-przez-sejm-glosami-pis,artykuly,398187,1.html [dostęp: 13.10.2016].

p. mal, 2016, Sejm odrzucit obywatelski projekt zaostrzajacy prawo aborcyjne, http://www.rp.pl/ Polityka/161009536-Sejm-odrzucil-obywatelski-projekt-zaostrzajacy-prawo-aborcyjne. html\#ap-1 [dostęp: 13.10.2016].

Steinem G. 1983, If Hitler Were Alive, Whose Side Would He Be On? [w:] eadem, Outrageous Acts and Everyday Rebellions, New York: New American Library.

Szczuka K., 2004, Milczenie owieczek. Rzecz o aborcji, Warszawa: Wydawnictwo W.A.B.

Święchowicz M., 2014, Aborcja po polsku, „Newsweek” nr 2.

ts/kk, 2016, Sejm odrzucit projekt ustawy zaostrzajacej prawo aborcyjne, http://www.tvn24.pl/ wiadomosci-z-kraju,3/debata-i-glosowanie-w-sejmie-nad-zakazem-aborcji,681643.html [dostęp: 13.10.2016].

Wejbert-Wąsiewicz E., 2012, Aborcja w dyskursie publicznym. Monografia zjawiska, Warszawa: Wydawnictwo Uniwersytetu Łódzkiego. 
Wprost, 2016, Projekt liberalizacji prawa aborcyjnego. Zobacz, jak głosowali posłowie, https://www. wprost.pl/kraj/10024377/Projekt-liberalizacji-prawa-aborcyjnego-Zobacz-jak-glosowali-poslowie.html [dostęp: 13.10.2016].

Zaremba-Bielawski Maciej, 2011, Higieniści. Z dziejów eugeniki, tłum. W. Chudoba, Wołowiec: Wydawnictwo Czarne.

\begin{abstract}
Abstrakt
Celem artykułu jest analiza języka wybranych stron funkcjonujących na portalu społecznościowym Facebook, podejmujących kwestię prawa kobiet do aborcji. Dość rygorystyczne prawo, charakter dyskursu publicznego, a także aktywność ruchu pro-choice, który dąży obecnie do zmian w prawodawstwie, sprawiają, że temat aborcji funkcjonuje w sferze tabu.
\end{abstract}

\title{
Słowa kluczowe
}

aborcja, przerwanie ciąży, płód, kobieta, prawa reprodukcyjne, feminizm

\section{Summary}

Womens' Hell - Contemporary Portrayral of the Right to Abortion in Mass Media. Casus of Womens' Enslavement or Their Emancipation?

The aim of this article is analysis of language and word choice on selected websites, Facebook; taking issue womens' right to abortion. Fairly rigorous law, the nature of public discourse, and the activity of pro-choice movement which is striving now to change in legislation, makes, that theme of abortion operates in the realm of taboo.

\section{Keywords}

abortion, termination, fetus, woman, reproductive rights, feminism 